\title{
Microplastic Pollution: An Overview of Current Scenario, Challenges, and Research Gaps
}

\author{
Amrik Bhattacharya and SK Khare* \\ Department of Chemistry, Enzyme and Microbial Biochemistry Laboratory, Indian Institute of Technology, India
}

Submission: November 12,2018; Published: January 22, 2019

*Corresponding author: SK Khare, Department of Chemistry, Enzyme and Microbial Biochemistry Laboratory, Indian Institute of Technology, Hauz-Khas, Delhi-110016, India

\begin{abstract}
Globally presence of Microplastics (MPs) in the environment is identified as one of the major environmental threat. MPs are small plastic fragments $(0.001-5 \mathrm{~mm})$ and are ubiquitous in the environment especially in the marine and freshwater ecosystems. Majorly, they originate as a degradation products of larger plastic materials, or directly originate from personnel care products and synthetic fabrics. Smaller size of MPs results in their ingestion by a wide range of aquatic organisms ranging from zooplankton to fish, implying the potential for microplastics to accumulate in the marine food web.

In this way, microplastics can potentially impact food safety and human health also. Recently presence of MPs in drinking water and table salt has sought the attention of worldwide researchers. In addition to that, hydrophobic nature of MPs also makes them as an active site for sorption of number of toxic persistent organic and inorganic contaminants and this too imparts toxicity to them. However, still our understanding with respect to ecological impact of MPs on the terrestrial environment is limited. There is also a need for comprehensive evaluation and assessment of MPs in different environmental systems in order to obtain a complete scenario of the extent of pollution. Toxicity evaluation of the same also needs to be assessed depthly. In the present review a brief overview of microplastic pollution, its toxicity assessment along with major challenges and mitigation options are discussed.
\end{abstract}

Keywords: Microplastic; Toxicity; Contaminants; Aquatic systems; Life forms

Abbrevations: PE: Polyethylene; PP: Polypropylene; PA: Polyamide; PVC: Polyvinyl Chloride; PS: Polystyrene; PUR: Polyurethane; PCP: Personal Care Products;

\section{Introduction}

Microplastic (MPs) now has emerged as an alarming environmental pollutant and its prevalence is now widely observed in various ecosystems. The term "microplastic" coined by Thompson et al. [1] in the year 2004 basically represents heterogeneous mixture of smaller plastic fragments in the size range of $0.001-5 \mathrm{~mm}$ [2]. They may originate either directly (primary sources) through engineered particles such as microbeads/microfibers widely used in Personal Care Products (PCPs) or through fragmentation of larger plastic particles as a result of various anthropogenic activities (secondary sources) viz. fragments of fishing gear, packages and drink bottles, synthetic textiles, car tyres, paints, and cosmetics [3,4]. Natural breakdown through UV rays of sunlight, microbial processes, or through thermal oxidative processes also account for fragmentation of large plastic particles into MPs [5].

MPs basically consists of six major types of plastic products namely, Polyethylene (PE), Polypropylene (PP), Polyamide (PA),
Polyvinyl Chloride (PVC), Polystyrene (PS), Polyurethane (PUR), and Polyethylene Terephthalate (PET) [6,7]. Prevalence of MPs is conclusively reported in marine and freshwater systems. They can easily transport from source areas by water currents and wind to long distance and finally distributed in the sea shore or the sediments or even in the pristine environment such as Antarctica [8-10]. At present, worldwide production of plastic is about 320 million tons and is rising exponentially. It is estimated that by 2050 it will reach 33 billion tons [11]. At a similar pace, microplastic pollution is also rising alarmingly. More recently, it has been estimated that $10 \%$ of plastics produced end up in oceans, comprising $60 \%-80 \%$ of the marine litter [1]. Since plastic/ microplastic are persistent in nature and widely distributed in marine system, these are considered as great threat to marine and other life forms $[4,12,13]$. The severity of the problem could be better perceived by various reports published recently on MP contaminations $[3,10,14-17]$. Most of these reports are from marine aquatic systems. 
Because of smaller size of MPs they are easily ingested by a wide range of lower organisms. Uptake and accumulation of MPs have been documented in various marine organisms ranging from planktonic species to fish and reported to cause deleterious effect on them vis-à-vis the marine food web $[13,18,19]$. In this way, MPs can potentially impact food safety and human health also through sea food [20]. The occurrence of MPs is as well demonstrated in various terrestrial systems. Nonetheless, our understanding of their ecological impact on aquatic and more prominently on terrestrial environment is very limited $[4,9]$. As per a recent analysis there has been no attempt to understand the tropic level transfer of MP among the food chain and possible implications on humans and other higher life forms [20].

The present article provides an overview of MPs in the environment and its eco-toxicological evaluation. Major challenges and possible controlling measures to combat MPs pollution are also highlighted in the present write-up.

\section{Toxicity associated with MPs and present status}

In aquatic systems, depending upon the density, MP particles may either be settling down at the sediment or float in the water. MPs are reported to be favorable site for formation of biofilm and may aggregate to settle down $[8,9,21,22]$. In aquatic systems concentration of MPs are higher in sediments than in the surface water [23]. Because of their smaller size they are easily interact with aquatic biota or ingested by the planktonic communities, invertebrates, and fishes [10]. Presence of MPs in different aquatic taxa has been reported by various researchers from international arena $[4,13,18,19,24]$. Presence of these MPs is reported to adversely affect the growth of organisms and thus affect the ecological functions [12]. The uptake of MPs by the organisms may lead to blockage of alimentary canal and associated appendages $[13,25]$, smaller MPs may even absorbed by the epithelial cells of intestinal tract and may pass to the circulatory system thereby causing the toxicity [25]. Through lower animals' MPs can easily pass from one tropic level to other through food chain $[5,24,26]$. Thus, there is a great need in studying internalized MPs by the marine organisms and their associated toxic effects on them as evidenced from various recently published literature.

MPs could even be transfer to higher order of food chain (including humans) through consumption of contaminated food or water [20]. Recently presence of MPs in table salts and drinking water raises concern as these products are directly taken by human and thus could be source of MPs to human beings. In addition to that direct inhalation of MPs from the atmosphere also acts as a prominent source of MPs to humans. Moreover, MPs as a vector for proliferation of antibiotic resistance human pathogenic microbes is reported by Imran et al. [27] and this pose a potential threat to living beings.

Threat from MPs is further compounded because of their hydrophobic nature and large surface area to volume ratio MPs are ideal platform for adsorption of various persistent organic contaminants namely polychlorinated bisphenols, dichloro diphenyl dichloroethylene, nonylphenol, polyaromatic Hydrocarbons (PAHs), and dichloro diphenyl trichloroethane [28-30] and inorganic contaminants in the form of heavy metals. Combination of the two may aggravate the toxicity $[28,30]$. Though presence of MPs in various environmental system, its ingestion by marine organisms and resulting toxic effects have captured the interest of researchers' world over to microplastic research. Yet the understanding on microplastic distribution, its toxicity on biota, and subsequent ecological impact are in infancy.

EU and Australia have initiated global programmes in this direction. Developing countries especially from Asia and Africa though facing huge problem of plastic waste contamination and disposal, has yet to initiate systematic studies and levels microplastic in different environmental system. Thompson et al. [1] for the first time reported widespread presence MPs in different locations of sea around Plymouth, UK. Thereafter no significant report on MPs came, and the area of research has largely been overlooked. However, in last 4-2 years this area of research has received considerable attention and number of reports on presence MPs and its environmental implications has tremendously increased owing to pervasive presence of MP in the environment and its associated toxic effects on living beings including humans [6]. In the midst of several studies on MPs there are still some challenges which need to be looked upon in order to gain comprehensive knowledge about this perilous pollutant. The same is highlighted in the next head.

\section{Challenges or gaps in the studies}

a. There is no uniform methodology for detection or quantification of MPs in environmental samples. Every reported method has some limitations (based on size or color) and this should be addressed seriously in order to suitably assess the levels of MPs in environmental samples [7].

b. Most of the reports on MPs are from marine and freshwater aquatic systems and reports of the same from terrestrial systems are limited. Thus, in order to figure out the extent of MPs levels, its fate and behavior in terrestrial ecosystems, there is a need to look into this aspect also.

c. From the available literature it could be make out that majority of research on MPs are being accomplish in Europe, North America, and Australia. Few research studies were also available from Brazil, Japan, and India. Since MPs pollution is global phenomenon so there need to expansively carry out evaluation of MPs in different parts of the world. This will present clear picture of the MP pollution around the world and severity of the problem.

d. Toxicological evaluation of MPs is not accurately demonstrated. Nevertheless, their presence in different life forms especially the lower aquatic biota is well documented. There is also a need to comprehensively evaluate the toxicity of MPs and its associated contaminants in different life forms 
so that possible toxic effects on humans and other higher life forms could be minimized [7].

e. Now since the ubiquitous presence of MPs is well known, this necessitates the development of suitable technology for clean up or recovery of these MPs from the contaminated environment. Now the futuristic studies should focus on this aspect.

\section{Mitigation or controlling measures}

At present there is no report of any technology or study through which it is possible to combat MPs pollution. Hence source reduction is the only options through which we can prevent present situation to reach further aggravate level [7]. Since it is difficult to circumvent the usage of plastic from daily life but reduce use will surely minimize the secondary sources of MPs. In addition to that avoiding the usage of plastic products and products designated as primary sources of MPs will too certainly help in controlling the primary source of MPs in the environment.

Use of biodegradable plastic materials as far as possible in place of synthetic plastic is another major option to minimize the plastic menace. Considering ubiquitous presence of MPs and its rising level in the environment, the role of policy makers to regulate the MP pollution from industries and other prominent sources is highly advisable. Furthermore, public awareness with respect to MPs pollution and its detrimental effects on environment is also one of the prominent ways to curb menace of MPs pollution.

Overall in could be concluded that microplastic pollution has reached to alarming situation. Its toxicity and other environmental implications now are easily visualized. Before the situation further deteriorates there is urgent need to check spread of MPs in the environment.

\section{References}

1. Thompson RC, Olsen Y, Mitchell RP, Davis A, Rowland SJ, et al. (2004) Lost at sea: where is all the plastic? Science 304(5672): 838.

2. Shim WJ, Hong SH, Eo SE (2017) Identification methods in microplastic analysis: a review. Analytical Methods 9: 1384.

3. Mason SA, Garneau D, Sutton R, Chu Y, Ehmann K, et al. (2016) Microplastic pollution is widely detected in US municipal wastewater treatment plant effluent. Environ Pollut 218: 1045-1054.

4. Barboza LGA, Vethaak AD, Lavorante BRBO, Lundebye A-K, Guilhermino L (2018) Marine microplastic debris: An emerging issue for food security, food safety and human health. Marine Pollution Bulletin 133: 336-348.

5. Sharma S, Chatterjee S (2017) Microplastic pollution, a threat to marine ecosystem and human health: a short review. Environmental Science and Pollution Research 24(27): 21530-21547.

6. Alimi OS, Budarz JF, Hernandez LM, Tufenkji N (2018) Microplastics and nanoplastics in aquatic environments: aggregation, deposition, and enhanced contaminant transport. Environ Sci Technol 52(4): 1704-1724

7. Rezania S, Park J, Din MFM, Taib S M, Talaiekhozani A, et al. (2018) Microplastics pollution in different aquatic environments and biota: A review of recent studies. Mar Pollut Bull 133: 191-208.
8. Sruthy S, Ramasamy EV (2017) Microplastic pollution in Vembanad Lake, Kerala, India: The first report of microplastics in lake and estuarine sediments in India. Environmental Pollution 222: 315-322.

9. Dai Z, Zhang H, Zhou Q, Tian Y, Chen T, et al. (2018) Occurrence of microplastics in the water column and sediment in an inland sea affected by intensive anthropogenic activities. Environmental Pollution 242: 1557-1565.

10. Reed S, Clarka M, Thompson R, Hughes KA (2018) Microplastics in marine sediments near Rothera Research Station, Antarctica. Mar Pollut Bull 133: 460-463.

11. Joo S, Cho I J, Seo H, Son H F, Sagong H-Y, et al. (2018) Structural insight into molecular mechanism of poly (ethylene terephthalate) degradation. Nature Communications.

12. Wu Q Tao H, Wong MH (2018) Feeding and metabolism effects of three common microplastics on Tenebrio molitor L Environ Geochem Health.

13. Windsor FM, Tilley RM, Tyler CR, Ormerod SJ (2019) Microplastic ingestion by riverine macroinvertebrates. Science of the Total Environment 646: 68-74.

14. Sul JAI, Costa MF (2014) The present and future of microplastic pollution in the marine environment. Environ Pollut185: 352-364.

15. Everaert G, Van Cauwenberghe L, De Rijcke M, Koelmans AA, Mees J, et al. (2018) Risk assessment of microplastics in the ocean: Modelling approach and first conclusions. Environmental Pollution 1930-1938.

16. Xu P, Peng G, Su L, Gao Y, Gao L, et al. (2018) Microplastic risk assessment in surface waters: A case study in the Changjiang Estuary, China. Marine Pollution Bulletin 133: 647-654.

17. Rillig MC, Bonkowski M (2018) Microplastic and soil protists: A call for research. Environmental Pollution 241: 1128-1131.

18. Jemec A, Horvat P, Kunej U, Bele M, Krzan A (2016) Uptake and effects of microplastic textile fibers on freshwater crustacean Daphnia magna Environmental Pollution 219: 201-209.

19. Amelineau F, Bonnet D, Heitz O, Mortreux V, Harding AMA, et al. (2016) Microplastic pollution in the Greenland Sea: Background levels and selective contamination of planktivorous diving seabirds. Environ Pollut 219: 1131-1139.

20. Carbery M, Connor WO, Thavamani P (2018) Trophic transfer of microplastics and mixed contaminants in the marine food web and implications for human health. Environ Int 115: 400-409.

21. Lobelle D, Cunliffe M (2011) Early microbial biofilm formation on marine plastic debris. Mar Pollut Bull 62(1): 197-200.

22. Kleinteich J, Seidensticker S, Marggrander N, Zarfl C (2018) Microplastics reduce short-term effects of environmental contaminants. Part II: Polyethylene particles decrease the effect of polycyclic aromatic hydrocarbons on microorganisms. Int J Environ Res Public Health 15(2): 287.

23. Thompson RC (2015) Microplastics in the marine environment: sources, consequences and solutions. In Bergmann M, Gutow L, Klages M (Ed.) Marine anthropogenic litter, Springer Open, pp. 185-200.

24. Cole M, Webb H, Lindeque PK, Fileman ES, Halsband C, et al. (2014) Isolation of microplastics in biota-rich seawater samples and marine organisms. Scientific Reports 4: 4528.

25. Cauwenberghe LV, Janssen CR (2014) Microplastics in bivalves cultured for human consumption. Environ Pollut 193: 65-70.

26. Pegado TSS, Schmid K, Winemiller KO, Chelazzi D, Cincinelli A, et al. (2018) First evidence of microplastic ingestion by fishes from the Amazon River Estuary. Mar Pollut Bull 133: 814-821.

27. Imran M, Das KR, Naik MM (2019) Co-selection of multi-antibiotic resistance in bacterial pathogens in metal and microplastic 
contaminated environments: An emerging health threat. Chemosphere 215: 846-857.

28. Browne MA, Niven SJ, Galloway TS, Rowland SJ, Thompson RC (2013) Microplastic moves pollutants and additives to worms, reducing functions linked to health and biodiversity. Current Biology 23(23): 2388-2392.

\section{This work is licensed under Creative} Commons Attribution 4.0 Licens

DOI: 10.19080/AIBM.2019.12.555836
29. Wang Z, Su B, Xu X, Di D, Huang H, et al. (2018) Preferential accumulation of small $(<300 \mu \mathrm{m})$ microplastics in the sediments of a coastal plain river network in eastern China. Water Res 144: 393-401.

30. Diepens NJ, Koelmans AA (2018) Accumulation of plastic debris and associated contaminants in aquatic food webs. Environ Sci Technol 52(15): 8510-8520.

\section{Your next submission with Juniper Publishers will reach you the below assets}

- Quality Editorial service

- Swift Peer Review

- Reprints availability

- E-prints Service

- Manuscript Podcast for convenient understanding

- Global attainment for your research

- Manuscript accessibility in different formats

( Pdf, E-pub, Full Text, Audio)

- Unceasing customer service

Track the below URL for one-step submission https://juniperpublishers.com/online-submission.php 